\title{
PENGEMBANGAN POTENSI LAHAN KAPAS Di KABUPATEN LAMONGAN MENGGUNAKAN GIS
}

\author{
Faizah \\ *) Pengajar Jurusan Teknik Sipil Universitas Yudharta Pasuruan
}

\begin{abstract}
ABSTRAKSI
Kapas merupakan tanaman serat yang penting di dunia. Serat utama dari tanaman kapas adalah rambut biji yang panjang, yang digunakan untuk membuat benang dan dipintal dalam pabrik tekstil, baik digunakan sendiri atau dikombinasi dengan tanaman lain, serat binatang atau serat sintetik. Serat kapas juga dibuat menjadi produk lain seperti benang jahit, tali dan jaring ikan. Potongan tekstil kapas dan kain digunakan dalam industri kertas untuk menghasilkan kertas tulis, buku dan kertas gambar. Serat pendek diproses menjadi produk-produk seperti kertas, benang, hiasan dinding, bahan peledak, plastik dan film fotografi. Bubur kertas serat pendek dibuat menjadi berbagai tipe kertas, tergantung pada kualitasnya. Serat pendek juga digunakan untuk memproduksi selulosa dan dan bahan pelekat. Tujuan Pengembangan Potensi Tanaman Kapas di Kabupaten Lamongan adalah Melakukan analisis kemampuan tanah di Kabupaten Lamongan, Melakukan analisis kesesuaian lahan untuk perkebunan kapas di Kabupaten Lamongan dan Melakukan analisis ketersediaan lahan dan arahan pengembangan perkebunan kapas di Kabupaten Lamongan. Metode yang dipakai dalam penelitian ini adalah dengan menggunakan Sistem Informasi Geografis (GIS) dengan analisis kemampuan lahan dan kesesuaian lahan. Mengacu pada SK Mentan No. 837/KPTS/UM/I/1980, maka di kabupaten Lamongan didapatkan 3 jenis kawasan, yaitu: Kawasan budidaya tanaman semusim/permukiman (79,19805139 ha), Kawasan budidaya tanaman tahunan (94,78127083 ha), Kawasan penyangga (7,300677751 ha). Kesesuaian lahan untuk tanaman kapas di kabupaten Lamongan ada 3 yaitu yang sesuai (48,419851 ha), sedangkan lahan yang tidak sesuai (3,379215 ha) dan cukup sesuai (129,480872 ha). Lahan untuk tanaman kapas yang eksisting atau yang sudah ada yaitu seluas 26,048673 ha, sedangkan lahan untuk pengembangan yaitu seluas 16,660723 ha.
\end{abstract}

Kata Kunci: Kesesuaian lahan, Kapas, SIG

\section{PENDAHULUAN}

Sektor Perkebunan di Kabupaten Lamongan turut memberikan andil yang cukup besar bagi perekonomian rakyat. Dari segi produksi, komoditi kapas Lamongan menempati urutan nomor 1 (satu) se Jawa Timur dan nomor 5 (lima) di Indonesia. Kabupaten Lamongan merupakan salah satu wilayah yang potensial untuk pengembangan kapas karena secara agroklimat di beberapa kecamatan kondisinya cocok untuk tanaman kapas. Selain itu sebagian besar dari petani di daerah ini telah menanam kapas secara turun temurun, jadi kapas bukanlah tanaman yang asing bagi sebagian besar petani Lamongan (www.deptan.go.id).

Luas areal yang telah ada di Lamongan pada tahun ini mencapai 1.200 ha.Sejak dilakukan pengembangan kapas di
Kabupaten Lamongan sampai saat ini telah terakumulasi dana guliran sekitar Rp 1,3 milyar yang berasal dari berbagai kegiatan kapas yang didanai oleh OECF maupun APBN. Komoditi kapas sebagai sektor perkebunan memiliki beberapa masalah dalam perkembangannya, salah satunya adalah terbatasnya jumlah personil di lapangan dan turunnya minat petani untuk meningkatkan hasil perkebunannya (RTRW Kabupaten Lamongan, 2006: 7).

Rendahnya minat petani menanam kapas itu dapat dilihat dari luas areal tanaman. Indonesia memiliki 500.000 hektar lahan yang sangat potensial untuk pengembangan tanaman kapas dengan kualitas yang tidak kalah dengan produk kapas dari Amerika Serikat dan Australia. Dari seluruh luas lahan yang potensial itu, hanya 35.000 hektar yang 
sudah dimanfaatkan. Jatim memiliki 32.000 hektar lahan yang potensial untuk pengembangan tanaman kapas terbesar di Lamongan, Trenggalek, dan Pacitan. Namun, luas lahan yang dipakai di Jatim hanya 3.000 hektar. Daerah yang berpotensi untuk pengembangan kapas meliputi Jatim de-ngan kapasitas 6.000 ton kapas berbiji, Jawa Tengah (8.000 ton), NTB dan NTT masingmasing (10.000 ton), dan Sulsel (30.000 ton). Produksi kapas di Indonesia rata-rata 500 kilogram per hektar. Jika dikerjakan secara profesional, produksi kapas bisa mencapai 2,5 ton per hektar (www.kompas.com).

Permasalahan yang muncul yaitu bagaimana cara mencari lahan yang tepat dan sesuai dengan kriteria penanaman yang diinginkan user untuk penanaman kapas tetapi dengan waktu yang lebih singkat dari cara manual.

Untuk mendukung pencarian lahan penanaman kapas yang selama ini masih dilakukan secara manual, digunakan Geographic Information System (GIS). Dalam GIS, data-data atribut dan data analog yang selama ini digunakan sebagai acuan dalam menentukan lahan penanaman kapas akan diubah menjadi data digital. Dari data digital akan diproses dengan geoprocessing yang akan menghasilkan data lokasi lahan penanaman kapas yang sewaktu-waktu dapat dilihat kembali dan di update sesuai kebutuhan pengguna.

Hasil dari implementasi dan evaluasi untuk mencari lahan yang sesuai untuk penanaman kapas, aplikasi SIG untuk peluang Investasi Tanaman Kapas di Kabupaten Lamongan dapat menemukan lahan yang sesuai untuk penanaman kapas dan lahan yang dihasilkan sesuai dengan realita sebenarnya.

Tujuan yang ingin dicapai dalam Pengembangan Potensi Tanaman Kapas di Kabupaten Lamongan adalah :

1. Melakukan analisis kemampuan tanah di Kabupaten Lamongan

2. Melakukan analisis kesesuaian lahan untuk perkebunan kapas di Kabupaten Lamongan

3. Melakukan analisis ketersediaan lahan dan arahan pengembangan perkebunan kapas di Kabupaten Lamongan

Metode yang dipakai dalam penelitian ini adalah dengan menggunakan Sistem Informasi Geografis (GIS) dengan analisis kemampuan lahan dan kesesuaian lahan.

\section{TINJAUAN PUSTAKA}

Kapas merupakan semak atau pohon kecil tahunan tinggi mencapai hinga $3 \mathrm{~m}$, hampir di semua bagian terdapat titik-titik kelenjar minyak berwarna hitam. Daun tersusun spiral, tepi rata, tulangdaun menjari. Bunga soliter, biasanya dengan cabang simpodial; kelopak bentuk cangkir, mahkota 5 tersusun seperti genting, kuning, putih, merah atau ungu, biasannya dengan titik merah, tua atau ungu pada bagian tengah. Buah kapsul, membulat hingga bulat telur. Biji bulat telur yang ditutupi oleh rambut panjang seperti wol dan kadang juga oleh rambut yang pendek.

Kapas ditemukan pada $47^{\circ} \mathrm{N}$ sampai $32^{\circ} \mathrm{S}$. Temperatur optimum untuk perkecambahan adalah $9-30^{\circ} \mathrm{C}$ dan temperatur minimum sekitar $14-15^{\circ} \mathrm{C}$, meski beberapa berkecambah pada suhu hingga $12^{\circ} \mathrm{C}$. Untuk pertumbuhan dan perkembangan yang optimum membutuhkan temperatur 25$30^{\circ} \mathrm{C}$. Cuaca dingin akan memperlambat pertumbuhan dan perkembangan dan kadang gagal dalam pemasakan. Kapas sensitif terhadap salju. Sinar cahaya yang cukup mendukung perbungaan, pembentukan biji dan hasil panen yang tinggi diperoleh pada daerah kering dengan irigasi yang bagus, misalnya di Arizona, Amerika Serikat. Tanaman ini tidak tahan naungan. Curah hujan selama masa pertumbuhan adalah 500-1500 $\mathrm{mm}$. Selama pemasakan membutuhkan cuaca kering karena curah hujan setelah buah membuka akan mengurangi kualitas serat. Ketika curah hujan selama masa pertumbuhan kurang dari $500 \mathrm{~mm}$, irigasi sangat penting. Karena sistem perakarannya yang dalam, kapas tahan kekeringan, tetapi musim kering yang panjang selama pembungaan dan pembuahan menyebabkan pengurangan hasil panen. Angin kencang akan merusak kecambah dan pembukaan buah. Kapas primitif biasanya sensitif pada cahaya, menjadi reproduktif pada cahaya pendek hingga medium, tetapi budidaya modern secara umum tidak sensitif pada cahaya dan dapat tumbuh pada kisaran laltitude yang luas dengan musim hujan sekitar 6 bulan. Kapas sangat tergantung pada kualitas tanah, tetapi memerlukan tanah yang dalam (permeabel terhadap air dan akar hingga kedalaman sedikitnya1.2 $\mathrm{m}$ ), dengan drainase yang cukup dan $\mathrm{pH}$ antara 5.5-8.5. Tanah yang sangat subur merangsang pertumbuhan vegetatif dan menyebabkan periode vegetatif yang panjang. Kapas relatif toleran terhadap garam dengan kandungan $0.5-0.6 \%$ secara normal tidak menyebabkan kerusakan, tetapi untuk 
tanaman budidaya berbeda dengan keadaan ini.

Perbanyakan kapas dilakukan dengan biji. Pengelolaan biji dan distribusi sangat penting untuk menjamin kualitas dan kemurnian biji. Biasanya biji diperlakukan dengan alat mesin dan kimia, dengan alasan ekonomi dan lingkungan. Biji kehilangan kemampuan hidupnya secara cepat jika kelembaban melebihi $10 \%$, tetapi biji dengan kandungan kelembaban $7 \%$ dapat disimpan di botol tertutup hingga 15 tahun. Perbanyakan kapas secara vegetatif dapat dengan stek, sambung pucuk atau cangkok. Ketika tumbuh sebagai tanaman tahunan, kapas dapat dipotong kembali, tetapi hal ini tidak disarankan. Kecepatan perkembangan, kemampuan bereproduksi dan sistem ketergantungan dengan perbanyakan kultur jaringan sangat sulit dilakukan. Sekarang telah dikembangkan metode untuk menghasilkan embrio somatik dalam jumlah besar dari kalus yang berasal dari eksplan hipokotil atau kotiledon Gossypium arboreum, Gossypium barbadense, Gossypium herbaceum dan Gossypium hirsutum. Kerapatan tanaman bervariasi tergantung pada kultivar, iklim dan karakteristik tanah, begitu juga metode pemanenan. Jarak antar garis $50-120 \mathrm{~cm}$ dan 20-60 cm di dalam garis. Diperlukan sekitar $10-20 \mathrm{~kg} / \mathrm{ha}$ biji, jarak $80 \times 30 \mathrm{~cm}$ (41 700 lubang/ha) dengan 2-4 biji per lubang. Biji tidak boleh ditaburkan dengan kedalaman tidak lebih $5 \mathrm{~cm}$. Persiapan tanah yang baik sebelum biji ditaburkan sangat penting dilakukan, karena seedling tidak melakukan penetrasi secara keras dan tidak bersaing bagus dengan gulma sampai mereka berumur 3 minggu. Gulma musim kering dapat dimatikan dengan pencangkulan. Parit diperlukan pada tanah yang kurang drainase. Kapas biasanya tumbuh bergantian dengan tanaman lainnya untuk mengontrol hama dan penyakit yang timbul dari tanah.

Sistem Informasi Geografis (SIG) merupakan suatu sistem informasi yang bereferensikan geografis yang diterapkan untuk mengelola informasi spasial, yang dapat digunakan oleh perencana dan pengambil keputusan yang berhubungan dengan datadata spasial (keruangan).

Berbagai pengertian tentang Sistem Informasi Geografis (SIG) dikemukakan oleh beberapa pakar, diantaranya Linden (1987) dalam Suharyadi (1992), mengemukakan bahwa Sistem Informasi Geografis (SIG) adalah sebuah sistem informasi untuk pengelolaan, penyimpanan, pemrosessan, atau manipulasi, analisis dan penayangan data, yang mana data tersebut secara spasial terkait dengan permukaan bumi. Tidak jauh berbeda dengan Linden, Burrough (1986) mendefenisikan Sistem Informasi Geografis (SIG) sebagai suatu sistem yang mempunyai referensi geografis untuk spesifikasi, perolehan, penyimpanan, mendapatkan kembali dan manipulasi data. Sementara itu untuk defenisi yang akurat, dapat diterima secara luas, yaitu : "sistem komputer yang mampu menangani dan menggunakan data yang menjelaskan tempat dipermukaan bumi".(PC UNDERSTANDING GIS, THE ARCIINFO METOHD, EDISI INDONESIA 1991)

Sistem Informasi Geografis (SIG) merupakan suatu sistem yang tepat untuk mengelola data-data spasial. Dalam SIG data dikelola dalam format digital dan data dalam kuantitas yang cukup besar dapat dikelola dan dipanggil kembali dalam waktu yang relatif singkat dengan unit yang relatif murah apabila telah tersedia dan digunakan sistem komputer. Selain itu SIG mempunyai kemampuan untuk memanipulasi data spasial dan atribut yang relevan serta intergrasi tipe data yang berbeda dengan analisis tunggal yang tidak mungkin dilakukan dengan operasi manual. Secara garis besar SIG terdiri dari dari empat subsistem yaitu: pemasukan data, penyimpanan dan pemanggilan data (data managemen), data manipulasi dan analisa, dan output data (menampilkan produk SIG).

Istilah kesesuai lahan disini mengikuti pengertian yang dikemukakan oleh FAO (1976) dalam Frame Word For Land Evaluation, ialah sistim klasifikasi kecocokan suatu lahan apabila dipergunakan untuk penggunaan tertentu.

Kesesuaian Iahan digunakan untuk maksud klasifikasi yang lebih detail, seperti: kecocokan untuk jenis tanaman tertentu, spesies pohon, tipe bangunan dan lain-lain. Sedangkan kesesuaian lahan pada klasifikasi dengan kemampuan lahan sklala peta pada umumnya lebih besar.

Evaluasi kesesuaian lahan menitik beratkan pada pencarian lokasi yang memiliki sifat-sifat positip terhadap keberhasilan produksi dalam penggunaanya. Ada tiga tahapan dalam melakukan evaluasi kesesuaian lahan, sebagai berikut:

- Penentuan persyaratan / parameter

- Pengumpulan data-data tentang karateritik/kualitas lahan

- Evaluasi data yang dilakukan dengan membandingkan antara persyaratan dengan karateristik/kualitas lahannya. 


\section{METODE PENELITIAN}

\section{Analisis Kemampuan Lahan}

Analisis kemampuan lahan adalah kajian terhadap kondisi fisik lahan pada suatu wilayah dan bertujuan untuk mengetahui karakteristik lahan yang menjadi batasan kesesuaian pemanfaatan suatu sumberdaya. Landasan dari analisis kemampuan Iahan dalam penelitian Surat Keputusan Menteri Pertanian No. 837/KPTS/UM/II/1980, lahan akan diklasifikasikan dalam 4 kawasan yaitu Kawasan Lindung, Kawasan Penyangga, Kawasan Budidaya Tahunan dan Kawasan Tanaman Semusim/Permukiman. Karakteristik lahan yang akan dievaluasi untuk menghasilkan fungsi kawasan adalah jenis tanah, topografi, iklim.

a. Topografi, yaitu menyangkut data kelerengan lahan yang dinyatakan dalam persentase kemiringan berdasarkan sudut kemiringan. Topografi sangat berperan untuk melihat kemungkinan erosi pada suatu wilayah.

b. Jenis Tanah, yaitu menyangkut kepekaan terhadap erosi, dimana tanah dibagi menjadi beberapa golonagn berdasar tingkat kepekatan erosinya.

c. Iklim, yaitu menyangkut curah hujan dalam kaitannya terhadap erosi.

Sebelum dilakukan analisis, terlebih dahulu skor masing-masing klasifikasi kawasan dalam ketiga peta tematik dimasukkan dalam tabel atributnya. Skor ini berdasarkan peraturan yang dikeluarkan oleh Menteri Pertanian yaitu SK Mentan No. 837/KPTS/UM/II/1980 sebagai berikut :

Tabel 1. Nilai Pembobotan Peta

\begin{tabular}{|c|c|c|}
\hline Peta Tematik & Klasifikasi Kawasan & Skor \\
\hline \multirow[t]{5}{*}{ Kelerengan } & $0-8 \%$ & 20 \\
\hline & $8-15 \%$ & 40 \\
\hline & $15-25 \%$ & 60 \\
\hline & $25-45 \%$ & 80 \\
\hline & $>45 \%$ & 100 \\
\hline \multirow[t]{5}{*}{ Jenis Tanah } & $\begin{array}{l}\text { Aluvial, tanah glei, planosal, } \\
\text { hidromorf kelabu,latorik air } \\
\text { tanah }\end{array}$ & 15 \\
\hline & Latosol & 30 \\
\hline & $\begin{array}{l}\text { Brown forest soil, noncolcic } \\
\text { brown, mediteran }\end{array}$ & 45 \\
\hline & $\begin{array}{l}\text { Andasol, loterik, gomosol, } \\
\text { potsol, podsolik }\end{array}$ & 60 \\
\hline & $\begin{array}{l}\text { Regosol, litosol, organosol, } \\
\text { rezina }\end{array}$ & 75 \\
\hline \multirow[t]{5}{*}{ Curah Hujan } & $<13,6 \mathrm{~mm} /$ hari & 10 \\
\hline & $13,6-20,7 \mathrm{~mm} /$ hari & 20 \\
\hline & $20,7-27,7 \mathrm{~mm} /$ hari & 30 \\
\hline & $27,7-34,8 \mathrm{~mm} /$ hati & 40 \\
\hline & $>34,8 \mathrm{~mm} /$ hari & 50 \\
\hline
\end{tabular}

Dari beberapa kriteria yang ada tersebut kemudian dijumlahkan nilai bobotnya untuk digolongkan menjadi 4 kriteria, yaitu:

a). < 75, kawasan budidaya tanaman semusim/permukiman

b). 75 - 125, kawasan budidaya tanaman tahunan

c). 125 - 175 kawasan penyangga

d). $>175$, kawasan lindung

\section{Analisis Kesesuaian Lahan Lahan}

Analisis kesesuaian lahan merupakan analisis yang bertujuan untuk mengungkapkan kesesuaian antara penggunaan lahan dengan potensi kemampuan lahannya, baik kondisi penggunaan lahan eksisting maupun rencana penggunaan lahan (terdapat dalam dokumen RTRW). Baik analisis kemampuan lahan maupun kesesuaian lahan menggunakan Sistem Informasi Geografis (GIS) dengan bantuan software ArcView versi 3.3. dengan metode overlay.

\section{HASIL DAN PEMBAHASAN}

\section{Analisa Kemampuan Lahan}

Dari hasil scoring data atibut dan overlay tiga peta yaitu peta kelerengan, jenis tanah dan curah hujan di Kabupaten Lamongan dan mengacu pada SK Mentan No. 837/KPTS/UM/II/1980, maka di kabupaten Lamongan didapatkan 3 jenis kawasan, yaitu:
a. Kawasan budidaya
tanaman

semusim/permukiman.

Untuk kawasan budidaya tanaman semusim/permukiman dengan luas 79,19805139 ha yang terdapat di wilayah bagian tengah sampai utara.

b. Kawasan budidaya tanaman tahunan

Untuk kawasan budidaya tanaman tahunan sebagian besar di wilayah selatan, dan ada sebagian kecil dibagian wilayah utara, luasnya mencapai 94,78127083 ha.

c. Kawasan penyangga

Untuk kawasan penyangga di Kabupaten Lamongan hanya terdapat sedikit sekali yaitu 7,300677751 ha yang berada di wilayah selatan, utara dan barat. 


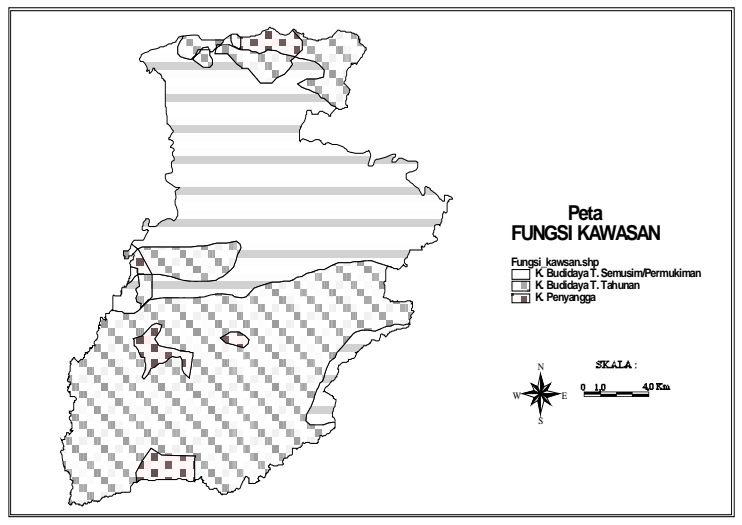

Gambar 1: Peta Fungsi Kawasan Kabupaten Lamongan

\section{Analisis Kesesuaian Lahan}

Analisis Kesesuaian Lahan Tanaman Kapas Analisis ini dilakukan untuk menemukan kelas kesesuaian lahan bagi komoditas kapas berdasarkan klasifikasi kesesuaian $\mathrm{S} 1, \mathrm{~S} 2$, dan $\mathrm{N}$, dimana untuk nilai S1 adalah lahan yang sesuai untuk tanaman kapas, S2 adalah cukup sesuai dan $\mathrm{N}$ adalah tidak sesuai. Peta tematik yang dipergunakan dalam analisis ini antara lain :

- Peta Curah Hujan

- Peta Kelerengan

- Peta Jenis Tanah

- Peta Ketinggian Lahan

Seperti dalam analisis sebelumnya, analisis kesesuaian lahan ini mempergunakan software Arcview 3.3. dengan metode overlay. Sebelum analisis dimulasi, terlebih dahulu skor kawasan dimasukkan dalam tabel atribut masing-masing peta sebagai berikut :

Tabel 2. Kriteria dan Faktor Pembobot Lahan Kapas

\begin{tabular}{|c|c|c|c|}
\hline \multirow[b]{2}{*}{ Kualitas Lahan } & \multicolumn{3}{|c|}{$\begin{array}{c}\text { Kelas Kesesuaian Lahan / Faktor } \\
\text { Pembobot }\end{array}$} \\
\hline & $\begin{array}{l}\text { Sesuai } \\
30\end{array}$ & $\begin{array}{c}\text { Cukup } \\
\text { sesuai } \\
20\end{array}$ & $\begin{array}{c}\text { Tidak } \\
\text { sesuai } \\
10 \\
\end{array}$ \\
\hline Jenis Tanah & $\begin{array}{l}\text { Groumo } \\
\text { sol }\end{array}$ & Aluvial & $\begin{array}{l}\text { Regosol } \\
\text { Latosol }\end{array}$ \\
\hline $\begin{array}{l}\text { Curah Hujan } \\
\text { (mm/tahun) }\end{array}$ & $<1500$ & $1500-2000$ & $2000-2500$ \\
\hline $\begin{array}{l}\text { Kelerengan } \\
\text { Lahan (\%) }\end{array}$ & $\begin{array}{c}0-2 \\
\% \\
2-15 \\
\% \\
\end{array}$ & $15-40 \%$ & $>40 \%$ \\
\hline $\begin{array}{l}\text { Ketinggian } \\
\text { (m. dpl) }\end{array}$ & $\begin{array}{l}100- \\
250\end{array}$ & $25-100$ & $0-25$ \\
\hline
\end{tabular}

Hasil tumpang susun (overlapping) 4 elemen parameter tersebut diatas akan diklasifikasikan menjadi 3 (tiga) tingkatan kesesuaian lahan. Untuk menentukan interval kelas dalam analisa lahan kapas suatu daerah digunakan rumus sebagai berikut :

$$
\begin{aligned}
\text { Interval kelas } & =\frac{\sum \text { tertinggi }-\sum \text { terendah }}{\sum \text { kelas }} \\
& =\frac{120-40}{3}=26,66=27
\end{aligned}
$$

Maka score kelas dapat ditentukan sebagai berikut :

1. Lahan yang tidak sesuai untuk kapas jika mempunyai score antara 40 - 67

2. Lahan yang cukup sesuai untuk kapas jika mempunyai score antara 67 - 94

3. Lahan yang sesuai untuk kapas jika mempunyai score antara 94 - 120

Dari hasil scoring data atibut dan overlay 4 peta tematika yaitu peta ketinggian, peta jenis tanah, peta kelerengan dan peta curah hujan maka didapatkan lahan kesesuaian lahan untuk tanaman kapas di Kabupaten Lamongan.

Tabel 3. Kesesuaian Lahan Tanaman Kapas Kabupaten Lamongan

\begin{tabular}{lr}
\multicolumn{1}{c}{ Kesesuaian } & \multicolumn{1}{c}{ Luas (ha) } \\
\hline Sesuai & 48,419851 \\
\hline Cukup Sesuai & 129,480872 \\
\hline Tidak Sesuai & 3,379215 \\
\hline
\end{tabular}

Dari hasil analisa scoring kesesuaian lahan untuk tanaman kapas didapatkan bahwa luas lahan yang cocok dan sesuai untuk ditanami kapas di kabupaten Lamongan cukup luas yaitu 48,419851 ha, sedangkan lahan yang tidak sesuai untk tanaman kapas hanya sebagian kecil saja yaitu sebesar 3,379215 ha dan sisanya cukup sesuai. Jadi hampir seluruh wilayah kabupaten Lamongan cocok untuk tanaman kapas. Jadi dapat disimpulkan bahwa tanaman kapas bisa dikembangkan di kabupaten Lamongan.

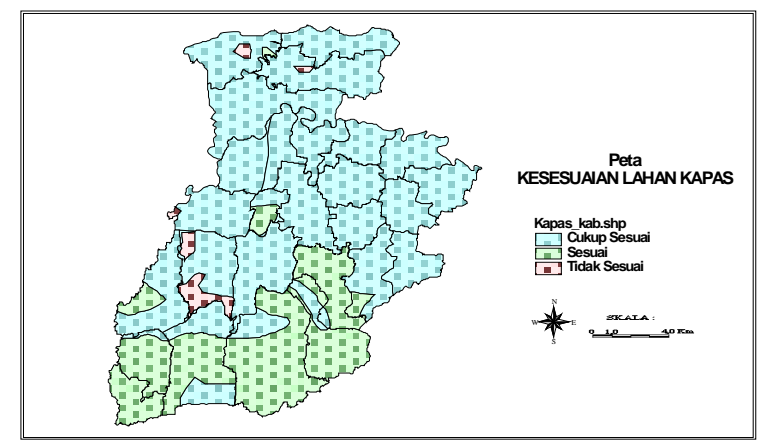

Gambar 2: Peta Kesesuaian Lahan Kapas Kabupaten Lamongan 


\section{Analisis Kesesuaian Lahan Tanaman Kapas berdasarkan Fungsi Kawasan}

Pada tahap proses analisis ini sama dengan tahapan analisis sebelumnya, yaitu dengan proses overlay dengan menggunakan software arcview 3.3. Untuk tahap analisis ini peta yang akan dioverlaykan adalah peta fungsi kawasan dan peta kesesuaian lahan kapas. Apabila analisis sebelumnya menggunakan nilai pembobotan atau scoring, untuk analisis ini tanpa menggunakan nilai pembobotan tetapi cukup mengoverlay baik data spsial maupun data atributnya dan dilakukan analisis dengan query.

\section{Tabel 4. Luas Lahan Kesesuaian Tanaman Kapas Berdasarkan Fungsi Kawasan Kabupaten Lamongan}

\begin{tabular}{lr}
\hline \multicolumn{1}{c}{ Fungsi Kawasan dan Tingkat kesesuaian } & \multicolumn{1}{c}{ Luas (ha) } \\
\hline Kawasan Penyangga & 7,300678 \\
\hline KBT. Semusim/Permukiman dan S1 Kapas & 1,680993 \\
\hline KBT. Semusim/Permukiman dan S2 Kapas & 77,517059 \\
\hline KBT. Semusim/Permukiman dan N Kapas & 0 \\
\hline KBT. Tahunan dan S1 Kapas & 46,738921 \\
\hline KBT. Tahunan dan S2 Kapas & 46,691725 \\
\hline KBT. Tahunan dan N Kapas & 1,350625
\end{tabular}

Dari tabel dapat dilihat bahwa lahan yang sesuai untuk tanaman kapas berada di kawasan budidaya tanaman tahunan seluas 46,738921 ha, sedangkan yang di kawasan budidaya tanaman semusim/permukiman adalah 1,680993 ha, maka dapat disimpulkan bahwa tanaman kapas masuk dalam kategori tanaman tahunan.

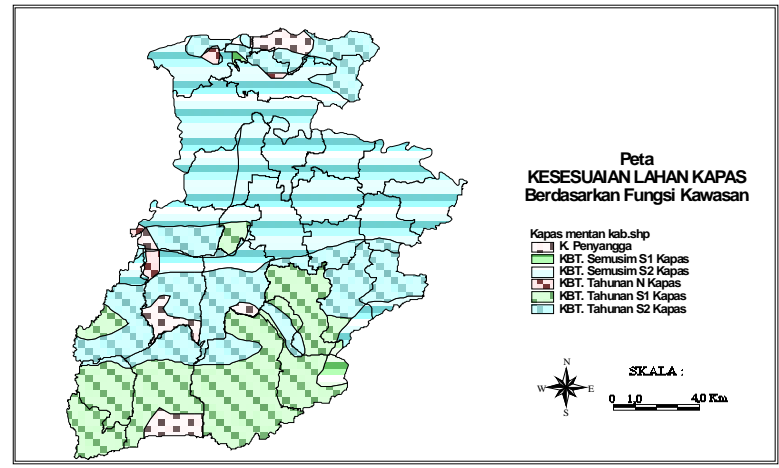

Gambar 3: Peta Kesesuaian Lahan Kapas berdasarkan Fungsi Kawasan Kabupaten Lamongan

\section{Analisis Ketersediaan Lahan \\ Analisis Ketersediaan Lahan berdasarkan Lahan Eksisting Kapas}

Analisis ketersedian lahan ini adalah untuk mengetahui lahan yang sesuai untuk tanaman kapas selain lahan eksisting untuk tanaman kapas. Proses analsis ketersedian lahan sama dengan proses analisis kesesuaian lahan berdasarkan fungsi kawasan yaitu menggunakan software arcview 3.3 dengan proses overlay data spasial dan data atribut. Peta yang digunakan untuk analisis ketersedian lahan ini adalah peta Kesesuaian lahan berdasar fungsi kawasan dengan peta eksisting lahan kapas. Setelah dilakukan overlay selanjutnya untuk proses analisanya dilakukan dengan mempergunakan tool tabel query sehingga akan didapatkan lahan kapas sesuai dengan fungsi kawasan berada lahan eksisting atau tidak.

Dari hasil analisa ini dapat diketahui diketahui ketersedian lahan yang sesuai untuk tanaman kapas yang berada di lahan eksisting dan yang bukan lahan eksisting. Ketersediaan lahan yang sesuai untuk tanaman kapas yang berada di kawasan budidaya tanaman tahunan dan berada di lahan eksisting seluas 27,837790 ha, sedangkan yang berada di kawasan budidaya tanaman semusim dan berada di lahan eksisting seluas 1,484720 ha. Sedangkan lahan yang sesuai untuk tanaman kapas yang berada di kawasan budidaya tanaman tahunan di luar lahan yang tersedia yaitu seluas 18,901130 ha dan yang berada di kawasan budidaya tanaman semusim seluas 0,196273 ha.

Tabel 5. Luas Ketersediaan Lahan Tanaman Kapas Kabupaten Lamongan

\begin{tabular}{|c|c|c|}
\hline \multicolumn{2}{|c|}{ Fungsi Kawasan } & \multirow{2}{*}{$\begin{array}{c}\text { Luas } \\
\text { Lahan (ha) } \\
7,300678\end{array}$} \\
\hline K. Penyangga & & \\
\hline \multirow{4}{*}{ KBT. Semusim } & S1 Kapas Eksisting & 1,484720 \\
\hline & $\begin{array}{l}\text { S1 Kapas Bukan } \\
\text { Eksisting }\end{array}$ & 0,196273 \\
\hline & S2 Kapas Eksisting & 1,058151 \\
\hline & $\begin{array}{l}\text { S2 Kapas Bukan } \\
\text { Eksisting }\end{array}$ & 76,458846 \\
\hline \multirow{6}{*}{ KBT. Tahunan } & S1 Kapas Eksisting & 27,837790 \\
\hline & $\begin{array}{l}\text { S1 Kapas Bukan } \\
\text { Eksisting }\end{array}$ & 18,901130 \\
\hline & S2 Kapas Eksisting & 8,200137 \\
\hline & $\begin{array}{l}\text { S2 Kapas Bukan } \\
\text { Eksisting }\end{array}$ & 38,491588 \\
\hline & N Kapas Eksisting & 0 \\
\hline & $\begin{array}{l}\text { N Kapas Bukan } \\
\text { Eksisting }\end{array}$ & 1,350625 \\
\hline
\end{tabular}




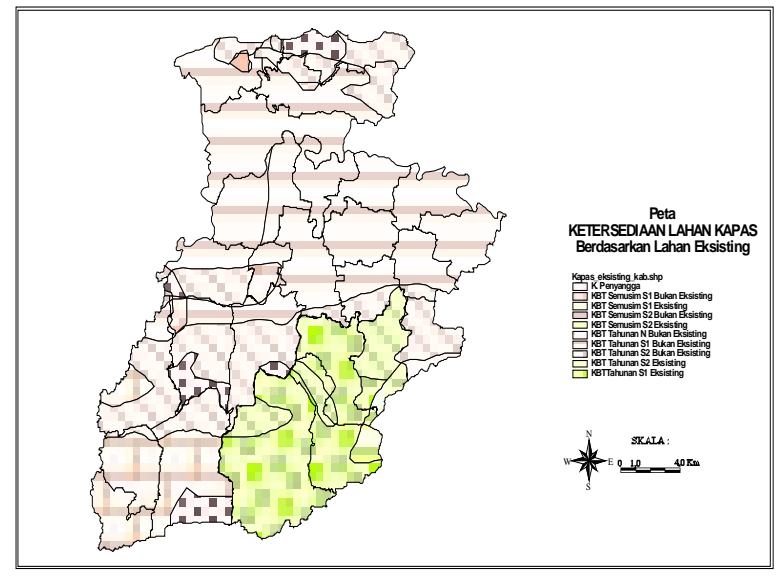

Gambar4: Peta Ketersediaan Lahan Kapas berdasarkan Lahan Existing Lahan Kapas Kabupaten Lamongan

\section{Analisis Ketersedian Lahan berdasarkan Landuse}

Analisis ini adalah analisis ketersediaan lahan kapas yang terakir dilakukan untuk mendapatkan luas lahan yang sesuai untuk tanaman kapas dan diluar lahan permukiman. Proses analisis ini seperti halnya analisis sebelumnya yaitu dengan melakukan overlay baik data spasial maupun data atribut dengan menggunakan software arcview 3.1. Adapun peta yang digunakan untuk analisis ini yaitu peta ketersedian lahan tanaman kapas dengan peta landuse kabupaten Lamongan. Sedangkan untuk analisisnya menggunakan query sehingga akan didapatkan luas lahannya.

Dari hasil overlay data spasial dan data atribut serta analisis query didapatkan ahwa lahan yang sesuai untuk kapas dan sudah tersedia atau eksisting di kabupaten Lamongan. terluas ada di kecamatan Sambeng 14,400713 ha, kecamatan Mantup 5,814148 ha dan di kecamatan Kembangbahu 5,254982 ha serta sebagian kecil di kecamatan Sugio dan kecamatan Tikung. Sedangkan untuk lahan pengembangan yang sesuai untuk tanaman kapas berada di kecamatan Ngimbang 6,009048 ha, di kecamatan Sukorame 3,584102 ha, di kecamatan Modo 1,253924 ha, di kecamatan Pucuk 1,202733 ha dan sebagian kecil ada di kecamatan Brondong, kecamatan Sugio, kecamatan Kembangbbahu, kecamatan Sambeng dan kecamatan solokuro.

Tabel 6. Ketersediaan Lahan Kapas (Landuse) Kabupaten Lamongan

\begin{tabular}{lr}
\hline \multicolumn{1}{c}{ Landuse } & \multicolumn{1}{c}{ Luas (ha) } \\
\hline Lahan Kapas Eksisting & 26,048673 \\
\hline Lahan Kapas Bukan & 16,660723 \\
Eksisting & 6,387047 \\
\hline Kawasan Penyangga & 27,869878
\end{tabular}

\begin{tabular}{lr} 
Hutan & 17,015749 \\
\hline Sawah & 69,532922 \\
\hline Tambak & 5,338136 \\
\hline Tegalan & 2,776100 \\
\hline Kebun & 9,347185 \\
\hline Rawa & 0,122795 \\
\hline
\end{tabular}

Dari tabel di atas dapat disimpulkan bahwa lahan untuk tanaman kapas yang eksisting atau yang sudah ada yaitu seluas 26,048673 ha, sedangkan lahan untuk pengembangan yaitu seluas 16,660723 ha. Luas ini setelah dikurangi lahan permukiman dan lain-lain. Dalam analisis ini kami hanya menggunakan lahan yang sesuai dengan tanaman kapas, sedangkan untuk lahan yang cukup sesuai untuk tanaman kapas tidak kami jadikan acuhan karena lahan yang cukup sesuai hampir mencakup semua kabupaten Lamongan. Jadi seandainya nanti tanaman kapas akan di kembangkan di kabupaten Lamongan itu akan sangat prospek sekali karena lahan yang ada di kabupaten Lamongan cukup sesuai.

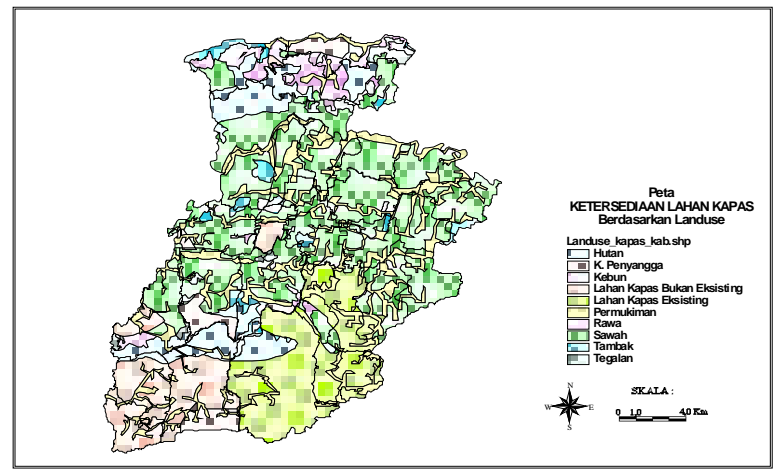

Gambar5: Peta Ketersediaan Lahan Kapas berdasarkan Landuse Kabupaten Lamongan

\section{KESIMPULAN}

Kesimpulan yang dapat diambil dari pengembangan potensi lahan kapas dengan menggunakan Sistem Informasi geografis yaitu:

1. Kemampuan Lahan di Kabupaten Lamongan mengacu pada SK Mentan No. 837/KPTS/UM/II/1980, maka di kabupaten Lamongan didapatkan 3 jenis kawasan, yaitu: Kawasan Penyangga (7,300677751 ha), Kawasan Budidaya Tanaman $(79,19805139$ ha) dan Kawasan Budidaya Tanaman Tahunan (94,7812708 ha).

2. Kesesuaian Lahan Tanaman Kapas di Kabupaten Lamongan terdiri dari 3 kategori kesesuain yaitu: Sesuai $(48,419851$ ha), Cukup Sesuai $(129,480872$ ha), dan Tidak Sesuai (3,379215 ha). 
3. Ketersediaan Lahan dan pengembangan tanaman kapas di Kabupaten Lamongan Lahan Kapas Eksisting (26,048673 ha) dan Lahan Kapas Bukan Eksisting (16,660723 ha).

\section{DAFTAR PUSTAKA}

Budiyanto, Eko., 2002. Sistem Informasi Geografis Menggunakan ArcView GIS. Penerbit Andi, Yogyakarta

Handoyo.S, 1997, Modul Sistem Informasi Geografi, Institut Teknologi Nasional, Malang.

http://www.kehati.or.id/florakita/browser.php?d ocsid=966. Didownlod pada tanggal 25 Juli 2009.

Prahasta.E, 2001, Konsep-Konsep Dasar Sistem Informasi Geografis, Penerbit Informatika, Bandung.

Surat Keputusan Menteri Pertanian Nomor : 837/Kpts/Um/11/1980, Tentang Kriteria Dan Tata Cara Penetapan Hutan Lindung. 